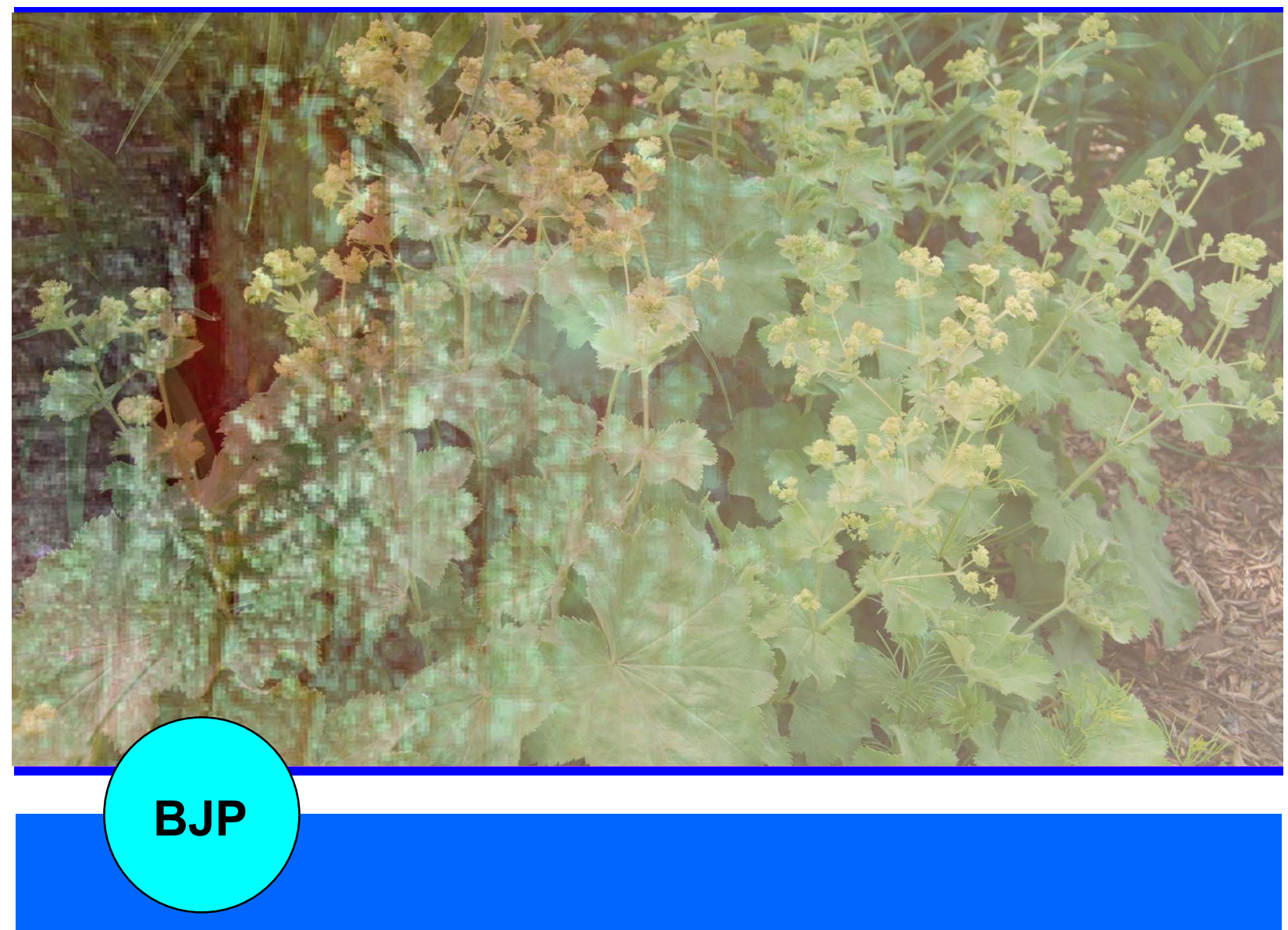

Bangladesh Journal of Pharmacology

Mini-Review

Medicinal plants with wound healing potential 
Abstracted/indexed in Academic Search Complete, Asia Journals Online, Bangladesh Journals Online, Biological Abstracts, BIOSIS Previews, CAB Abstracts, Current Abstracts, Directory of Open Access Journals, EMBASE/Excerpta Medica, Global Health, Google Scholar, HINARI (WHO), International Pharmaceutical Abstracts, Open J-gate, Science Citation Index Expanded, SCOPUS and Social Sciences Citation Index;

ISSN: $1991-0088$

\section{Medicinal plants with wound healing potential}

\section{Sayeed Mohammed Firdous and Dippayan Sautya}

Department of Pharmacology, Calcutta Institute of Pharmaceutical Technology and Allied Health Sciences, Banitabla, Uluberia, Howrah, West Bengal, India.

\begin{tabular}{|c|c|}
\hline Article Info & \\
\hline Received: & 20 May 2017 \\
\hline Accepted: & 29 January 2018 \\
\hline Available Online: & 10 February 2018 \\
\hline DOI: $10.3329 /$ bjp.v & 3i1.32646 \\
\hline $\begin{array}{l}\text { Cite this article: } \\
\text { Firdous SM, Sau } \\
\text { plants with wound } \\
\text { Bangladesh J Phar } \\
52 \text {. }\end{array}$ & $\begin{array}{l}\text { ya D. Medicinal } \\
\text { healing potential. } \\
\text { tacol. 2018; 13: 41- }\end{array}$ \\
\hline
\end{tabular}

\begin{abstract}
Wound occurs due to disruption of soft tissues that results from injury. Recently many medicinal plants have been demonstrated for wound healing potential through in vivo and in vitro preclinical models and their mechanisms of wound healing has also been reported. Medicinal plants have been reported to show wound healing potential via angiogenesis, activation of NF$\kappa \mathrm{B}$, favoring pro-inflammatory cytokines, increased expression of inducible nitric oxide synthase (iNOS) and alpha 1 type 1 collagen, and anti-oxidant activity. Thus, in this review, an attempt was made to give an insight into the recently reported medicinal plants with wound healing mechanisms which could be beneficial in therapeutic practice and development of new wound healing drugs for human use.
\end{abstract}

\section{Introduction}

A wound can be defined as a disruption of cellular and anatomic continuity of a tissue with or without microbial infection. Disruption of epithelial tissue of the skin with the distraction of functional continuity of living tissue occurs in wound due to physical, chemical, thermal, immunological, and microbial exploitation (Lazarus et al., 1994). If wound remains untreated may lead to pain, inflammation, infection, and sometimes organ failure (Kumar et al., 2007). Healing of wound occurs by complex series of events such as inflammatory phase, proliferative phase, and remodeling phase (Chan et al., 2008).

Herbal medicine is a part of human health care for thousands of years. Myriad of chemical constituents obtained from herbs are active against a number of diseased condition. As per the World Health Organization (WHO) reports more than $80 \%$ of the population in this world are dependent on herbal medicine (Ekor, 2013; Priya et al., 2002). Recently many plant extracts have been reported for wound healing activity and their cellular mechanism of wound healing has been studied extensively. It has been demonstrated that many plant extracts processed wound healing via angiogenesis (Mirmalek et al., 2015; Shen et al., 2017), activation of NF-kB (Nicolaus et al., 2017), favoring proinflammatory cytokines (Joshi et al., 2016), upregulation of iNOS (Pereira et al., 2016) and alpha-1 type-1 collagen (Krishnappa et al., 2016), fibroblast proliferation (Seyed et al., 2016; Öz et al., 2016), and anti-oxidant activity (Joshi et al., 2016). Thus, the aim of this review was to collect information about the cellular mechanisms of wound healing plants recently reported by the investigators and present them in an organized or systematic way.

This mini-review comprises scientific (peer-reviewed) data available in international databases (PubMed, Science Direct, and Elsevier) and international as well as local scientific journals that are not indexed in these databases but are available online in Google Scholar or repositories and libraries of different academic institutions have been also included. In such a way, the present review describes a simple and efficient review of recently reported medicinal plants with wound healing potential. 


\section{Healing of Wound}

Healing of wound occurs through an inflammatory phase, proliferative phase, and remodeling phase. Inflammatory phase starts instantly after the injury which lasts up to 48 hours and in some cases up to two weeks. Hemostatic mechanisms of this phase instantly stop bleeding via vasoconstriction and aggregation of platelets. Then vasodilatation and phagocytosis occur at the site of the wound and produce inflammation ( $\mathrm{Li}$ et al., 2007).

Proliferative phase starts after inflammatory phase and lasts from two days to three weeks. In this phase collagen fibers accumulate and neovascularization occurs. Edges of the wound are pulled together and reduced the wound area and then epithelial tissues are generated over the site of the wound (Guo and DiPietro, 2010).

Remodeling phase lasts up to three weeks to two years. In this phase, cross-linking between the collagen fibers through vitamin C-dependent hydroxylation increased the tensile strength of the tissue (Guo and DiPietro, 2010).

\section{Medicinal Plants with Wound Healing Poten- tial}

Many medicinal plants have been reported to show wound healing activity. Extensive investigation has been carried out in the field of wound healing management by medicinal plants. Some recent studies on medicinal plants with significant wound healing activity are illustrated as follows:

\section{Alchemilla mollis and Alchemilla persica}

Plants of Alchemilla genus are perennial belonging to the family Rosaceae and popularly known as "Lady's mantle" (ESCOP Monographs, 2003; Gruenwald et al., 2000). Species of Alchemilla have been reported for the treatment of dysmenorrhea, gastrointestinal disorders, inflammation of the mouth and throat, eczema and skin rashes (Kupeli Akkol et al., 2015). Alchemilla mollis is traditionally used for the treatment of wounds and excessive menstruation (Makau et al., 2013; Trendafilova et al., 2011; Yarnel and Abascal, 2009). In addition, A. mollis has been reported for the antiviral, astringent, diuretic, antispasmodic and anti-oxidant activities due to the presence of phenolic content such as tannins and flavonoids (Makau et al., 2013; Trendafilova et al., 2011).

Ointments of an aqueous-methanol extract of aerial and roots of $A$. mollis were evaluated for wound healing activity by linear incision and circular wound models in Wistar rat. The ointment significantly increased the tensile strength $(39.3 \%)$ and rate of wound contraction
$(51.4 \%)$ in linear the incision and circular wound models respectively compared to control rat. It also increased the hydroxyproline content. Histological study revealed fibroblast proliferation, epithelization, formation of collagen, and neovascularization (Öz et al., 2016). The ointment of $A$. persica also showed similar result (Öz et al., 2016).

\section{Aloe vera}

Aloe vera is commonly known as aloe or Gwar patta (Hindi), belonging to the family Liliaceae. This plant is used in digestive problems, asthma, peptic ulcer, skin irritation, burns, wound, eczema, acne, psoriasis, dermatitis and diabetes (Puvabanditsin and Vongtongsri, 2005; Reuter et al., 2008; Mohamed, 2011; Yagi et al., 2011). Fresh juice of this plant leaf contains $96 \%$ water and mucilage. The main constituents of the mucilage are D-glucose and D-mannose, tannins, steroid, enzymes, plant hormones, amino acids, vitamins and minerals.

It has been demonstrated that oral administration of mucilage of $A$. vera to type II diabetes Wistar rat improves the trend of wound healing by increasing in the expression of vascular endothelial growth factor (VEGF) and transforming growth factor- $\beta 1$ (TGF- $\beta 1$ ) which stimulates the fibroblast for reconstruction of extracellular matrix (Atiba et al., 2011; Mirmalek et al., 2015).

In a study, the effect of $A$. vera gel was investigated on round wound model in male rat. It was found that $A$. vera gel significantly reduced the wound thickness and altered the neutrophil, macrophage and fibroblast cells as compared with control group (Takzare et al., 2009).

Wound healing property of filtered A. vera aqueous extract was investigated on excision wound model in Sprague Dawley rat. Application of $1.5 \mathrm{~mL}$ of aqueous extract of $A$. vera on the lesion caused significant wound contraction from days 15 to 20 post-injury. The extract also significantly decreased the number of lymphocytes and macrophages and increased the number of new blood vessels (Oryan et al, 2010).

In another study, the effect of $A$. vera gel ethanolic extract on excision and incision wound was evaluated in streptozotocin-induced diabetic Wistar rat. Oral administration of $A$. vera gel ethanolic extract $(300 \mathrm{mg} /$ $\mathrm{kg}$ /day) for 9 days to diabetic rat significantly reduced the blood glucose level, improved the plasma insulin level, increased DNA and glycosaminoglycans aid to the healing of excision wound in diabetic rat. In addition, the extract also significantly increased the tensile strength in the incision model (Daburkar et al., 2014).

In 2013, Eghdampour et al., conducted a randomized clinical trial on the impact of $A$. vera on perineal healing 
after episiotomy in 111 qualified primiparous women admitted in Lolagar Hospital, Tehran, Iran. Patients were categorized into control group $(n=1)$ and experimental group $(n=2)$. Women in the experimental group $(n=2)$ were allowed to apply $A$. vera ointment every 8 hours for five days. The control group $(n=1)$ used hospital routine on episiotomy for five days. Collections of data were done by demographic questionnaire and redness, edema, ecchymosis, discharge and approximate scale (REEDS) which investigated the episiotomy healing before and five days after intervention in two groups. There was no significant difference in the demographic and other intervening variables in three groups. After delivery, the mean REEDS in five days showed a significant difference in the control and experimental groups. Thus, A. vera ointment significantly increased the speed episiotomy wound healing (Eghdampour et al., 2013).

From the above studies, it can be concluded that $A$. vera plant is having potential wound healing activity.

\section{Aloe littoralis}

A. littoralis Baker is the plant of genus Aloe belonging to the family Asphodelaceae. A. littoralis is a typical species cultivated in Iran (Soltanipoor, 2006). Persian scientists mentioned wound and burn and antiinflammatory properties of this plant (Hajhashemi et al., 2012).

Gel formulations of A. littoralis (12.5 and 100\% w/v Aloe mucilage in carbomer base) $500 \mathrm{mg}$ daily were evaluated in 24 days burn wound model in Wistar rat. $100 \%$ Aloe gel formulation and A. littoralis raw mucilaginous gel (500 mg daily) were evaluated in the incision wound model. In burn wound model, the gel formulations of A. littoralis (12.5 and $100 \% \mathrm{w} / \mathrm{v}$ Aloe mucilage in carbomer base) showed significant wound healing and $100 \%$ Aloe gel formulation and A. littoralis raw mucilaginous gel significantly healed incision wound (Hajhashemi et al., 2012).

\section{Caesalpinia ferrea}

Caesalpinia ferrea Mart (Caesaalpinioideae) is a leguminous plant distributed in Brazil. The bark of this plant is used in folk medicine to treat enterocolitis (Balbach, 1972), rheumatism, cancer (Nakamura et al., 2002) and wounds (Braga, 1976). Aqueous extract of barks of $C$. ferrea have been investigated for antiulcer (Bacchi and Sertie, 1994), anti-inflammatory and analgesic (Carvalho et al., 1996), antimicrobial (Sampaio et al., 2009) and antitumor (Nakamura et al., 2002) activities.

Cutaneous wound healing of ointment composed of bark powder of $C$. ferrea mixed with sterile vaseline was evaluated in mongrel goats. The ointment was found to reduce the wound area and complete epithelialization on $21^{\text {st }}$ day. On the other hand, microbiological evalua- tion showed the presence of Enterobacteriaceae and Staphylococcus aureus only in control group but not in treatment group (Oliveira et al., 2010).

To find out the mechanism of wound healing effect, the polysaccharide-rich extract of C. ferrea stem bark was investigated. It was found that the polysaccharide-rich extract reduced the wound area, leukocyte infiltration, vascular permeability, and stimulated angiogenesis, fibroplasias, collagen deposition and epithelial layer formation in Wistar rat. It also reduced the tumor necrosis factor- $\alpha$ (TNF- $\alpha$ ) expression, and the levels of prostaglandin E2, interleukin-1, malondialdehyde (MDA), total protein and myeloperoxidase (MPO). Moreover, it increased the expression of iNOS and TGF$\beta$ (Pereira et al., 2016).

\section{Calendula officinalis}

Calendula officinalis (Asteraceae) flowers have a long lasting traditional use in ethnopharmacology. This plant, also known as pot marigold, has been cultivated in Europe for centuries and used all over the world due to its medicinal properties (Muley et al., 2009). The use of preparations from Calendula flowers has a long-lasting tradition for the external treatment of inflammation and wound (Basch et al., 2006; Leach, 2008).

The ethanolic extract of C. officinalis flowers showed a significant decrease of the presence of fibrin and hyperemia when compared to the control group at $4^{\text {th }}$ and $7^{\text {th }}$ post-operative days in cutaneous wound model in Wistar female rat. There was no major difference in the hemorrhage, inflammatory infiltration, epithelialization and hyperplasia of epithelial cells between the analyzed groups. The ethanolic extract also showed increase in collagen deposition at $4^{\text {th }}$ and $7^{\text {th }}$ postoperative days. Immunohistochemical evaluation revealed an increase in the number of blood vessels and VEGF expression in the dermis (Parente et al., 2012).

Wound healing activity of gel of ethanolic extract of $C$. officinalis flowers (5, 7 and 10\%) was studied on the cutaneous wound healing in Sprague Dawley rat. The gel reduced wound size in rat when compared to control rat. $7 \%$ gel showed highest tensile strength. At microscopic level, the treated tissue at $14^{\text {th }}$ post-injury day showed epithelialization, few macrophages, lymphocytes, fibroblasts and loops of new blood vessels (Shafeie et al., 2015).

The mechanism of C. officinalis tincture cell viability and wound closure was studied. The tincture was found to increase the proliferation of Swiss albino mouse fibroblast cells (NIH-3T3), Human primary dermal fibroblast (HDF) and Human Caucasian fibroblast-like fetal lung cell (WI38) cells. In scratch assay, the tincture showed the migration of NIH-3T3, HDF and WI38 cells. In presence of phosphatidylinositol-3-kinase (PI3K) inhibitors (wortmannin and LY294002) C. officinalis tincture 
failed to migrate NIH-3T3, and WI38 cells which indicate fibroblast migration by $C$. officinalis tincture is most probably via the activation of PI3K pathway. The same study also demonstrated that inhibition of the PI3K pathway reduces the pAkt expression and thus decreased cell proliferation (Dinda et al., 2015).

In another study, the $n$-hexane, ethanolic, and aqueous extracts of C. officinalis flowers were tested on the inflammatory phase of wound healing on human immortalized keratinocytes and dermal fibroblast cells. The $n$ hexane extract was found to increase the activity of transcription factor NF-kB and the extract also increased the chemokine (Interleukin-8) in human immortalized keratinocytes. Migration and spreading of keratinocytes were little influenced in the scratch assay (Nicolaus et al., 2017).

Synergistic effect of hydroalcoholic extract of C. officinalis leaves in combination Ocimum basilicum leaves in form of carbopol gel was assessed in excision and burn wound model on Swiss albino mice. In both the models, the formulation showed a significant reduction in the period of epithelialization and increase in the rate of contraction of the wound which may be due to synergism (Sengupta, 2017).

\section{Citrus tamurana}

Citrus tamurana (Rutaceae) is a citrus crop of Miyazaki, Japan. This crop has been traditionally used as a supplement to increase digestion and appetite, relieve flatulence and abdominal distention and helps in respiratory difficulties and in the prevention of cough. Peel extract of C. tamurana has been reported to inhibit the cytochrome $\mathrm{P}_{450}$ 3A (Fujita et al., 2003) and midazolam 1-hydroxylase activity of human CYP 3A (Hosoi et al., 2006). Moreover, C. tamurana has been reported to suppress the loss of bone in ovariectomized rat (Yamaguchi et al., 2012).

To find out whether C. tamurana facilitates the process of in vitro wound healing, the effect of water extract of peels of C. tamurana was studied on the proliferation of skin fibroblast (TIG-119). The extract showed inhibition of proliferation of TIG-119 cells at higher concentration $(>1 \mathrm{mg} / \mathrm{mL})$ but at lower concentration $(0.1,0.25,0.50$, and $0.75 \mathrm{mg} / \mathrm{mL}$ ) it exhibited linear and time-dependent TIG-119 cells proliferation. In scratch wound healing model, the extract increased the migration of cells towards the wounded area. The extract $(0.8 \mathrm{mg} /$ $\mathrm{mL}$ ) also accelerated the $\mathrm{G}_{2}$ and $\mathrm{M}$ phases of cell cycle. The extract increased the expressions of Rac-1, Rho-A, and Cdc-42 m-RNA and cyclin-dependent kinase 1 and 2 (Cdk-1 and 2) gene. However, it did not induce the protein level of Cdk-1 and 2 (Madhyastha et al., 2013).

\section{Cynodon dactylon}

Cynodon dactylon is a perennial grass belonging to the family Poaceae (Sastry and Kavathekar, 1990). This plant has various medicinal properties. Traditionally farmers apply crushed leaves to prevent bleeding from minor wounds (Oudhia, 1999). The roots of this plant in the form of a paste with water are taken against fever (Natarajan and Paulsen, 2000). The aqueous fluid extract of the rhizome is used as anti-inflammatory, diuretic, antiemetic, purifying agent and also in dysentery (Kirtikar and Basu, 1980). This plant has been reported to possess antidiabetic (Singh et al., 2008a), antiulcer (Patil et al., 2005), diuretic, antimicrobial (Artizzu et al., 1996), hepatoprotective (Singh et al., 2008b), cardioprotective (Najafi et al., 2007), and immunomodulatory (Manga-thayaru et al., 2009) activities.

Topical application of carbopol gel formulation of aqueous and alcoholic extracts of C. dactylon plant showed rapid wound contraction in excision wound model in Wistar rat. In incision wound model, gel formulation of both aqueous and ethanolic extracts increased the tensile strength (Dande and Khan, 2012).

Application of ointment of the hydromethanolic extract of C. dactylon plant showed increased collagen deposition and decreased inflammatory cells infiltration and necrosis at $21^{\text {st }}$ post-surgery day in Wistar rat (Kumar and Kashyap, 2013).

Moreover, wound healing activity of the ointment of hydroalcoholic extract $C$. dactylon plant was precliniccally and clinically evaluated. In the preclinical study, wound contraction size, wound index, healing period, tensile strength of the wound, DNA, RNA, total protein and hydroxyproline of treated group were measured and significantly better result was found in C. dactylon ointment-treated group. C. dactylon ointment-treated group also showed epithelialization, collagen deposition and generation of new blood vessels. In the clinical study, there was significant generation of granulation and epithelial tissue. Polymorph (\%), lymphocytes (\%) and erythrocyte sedimentation rate (mm/hour) were also significantly improved (Biswas et al., 2017).

In another study, flavonoid fraction of C. dactylon was revealed wound healing property in Swiss albino mice. This fraction was found to decrease the lipid peroxidetion and increased collagen, protein and hexosamine content in tissue (Saroja et al., 2012).

\section{Delonix elata}

Delonix elata is a tree species belonging to the family Fabaceae (Leguminosae). Its leaf and bark are used to relieve pain, joint stiffness, inflammation, and arthritis (Hegazi, 2011).

Wound healing activity of simple 5 and $10 \%$ ointment of hydro-ethanolic $(70 \%)$ and aqueous extract of D. elata flowers were evaluated in excision, incision and dead 
space wound model in Wistar rat. Both the extracts showed a significant increase in wound contraction and epithelialization in excision wound model, tensile strength in incision wound model and formation of granuloma tissue with elevated hydroxyproline content in dead space wound model. Histopathological study revealed skinny epidermis with the hair follicle and inflammatory cells in the dermis (Mohd et al., 2012).

Aqueous and ethanolic extract of the leaf and bark of $D$. elata $(0.8 \mathrm{mg} / \mathrm{kg})$ were evaluated for the wound healing activity in Wistar rat. Both the extract increased the rate of wound contraction and also increased the serum total protein, ascorbic acid, and zinc. Protease activity was found to decrease in the treatment group (Sunday et al., 2014).

Beside this, wound healing activity of D. elata bark extract and isolated compound quercetin-3-rhamnopyranosyl-(1-6) glucopyranoside (QRPG) were assessed in Wistar rat. Topical application of the ointment of $D$. elata bark extract and QRPG showed rapid epithelialization and wound contraction and also increased the tensile strength. Both the ointment and QRPG increased the hydroxyproline, hexosamine, and uronic acid content. Moreover, the ointment and QRPG also upregulated the expression of alpha- 1 type- 1 collagen encoded by Col 1a (I) gene contributes to wound healing (Krishnappa et al., 2016).

\section{Drypetes klainei}

Drypetes klainei (Putranjivaceae) is traditionally used by Baka pygmies in Cameroon in the wound healing process and for the burn. Fine powder of stem bark is applied on the skin injury or consumed along with water. There are very fewer data available on $D$. klainei and for the validation of the traditional use of D. klainei by Baka Pygmies (Ngueyem et al., 2008; Brusotti et al., 2013, Cesari et al., 2015) wound healing property of water, dichloromethane, and methanolic extract of Drypetes kalinei stem bark was evaluated. It was found that water, dichloromethane, and methanolic extract increased the murine and human fibroblast cell viability and migration which was determined by scratch assay. The methanolic extract exhibited highest activity (Brusotti et al., 2015).

\section{Ephedra alata}

Ephedra alata is a perennial tough shrub belonging to the family Ephedraceae (Natho and Mandaville, 1991). In folk medicine, this plant is used for treat cancer. Moreover, E. alata is also suggested by some research group for the treatment of diabetes mellitus (Jaradat et al., 2016; Shabana et al., 1990).

An ointment prepared from the extract of E. alata was accessed for wound healing activity by excision and burn wound model in male healthy adult Syrian hamster. It was found that the ointment enhanced the fibrosis, improved healing of wound ulcers and deposition of collagen fibers but it showed no such improvement in the burn wound. The ointment increased the fibrosis in excision wound ulcers (Kittana et al., 2017).

\section{Hibiscus rosa-sinensis}

Hibiscus rosa-sinensis (Malvaceae) is a glabrous shrub. This plant is widely cultivated in the tropics as an ornamental plant. This plant has been reported to possess various medicinal properties including antitumor, antihypertensive, anti-oxidant and antiammonemic (Hou et al., 2005; Hirunpanich et al., 2006; Chang et al., 2006; Herrera-Arellano et al., 2004). The leaves and flowers help in hair growth and ulcer healing (Ali and Ansari, 1997; Kurup et al., 1979). Moreover, flowers are also has been found to be effective for the treatment of arterial hypertension and have antifertility activity (Singh et al., 1982; Sethi et al., 1986).

The ethanolic extract of $H$. rosa-sinensis flowers was accessed for the wound healing activity in excision, incision and dead space wound model in Sprague Dawley rat. The extract at the dose of $120 \mathrm{mg} / \mathrm{kg} /$ day in drinking water showed an increase in epithelialization and wound contraction. The extract also showed higher skin-breaking strength, granulation tissue and hydroxyproline content (Nayak et al., 2007).

The ointment (5 and 10\% w/w) of ethanolic extract $H$. rosa-sinensis flower was studied in excision, incision, and dead space wound models in Wistar rat. The extract increased cellular proliferation and collagen synthesis and enhanced wound contraction and epithelization in excision wound. In incision wound model, it increased the wound breaking strength. In the dead space wound, the extract increased the weight of granulation tissue and hydroxyproline content (Bhaskar and Nithya, 2012).

In another study, wound healing activity of ethanolic extract of $H$. rosa-sinensis leaf was evaluated in Wistar rat. The extract enhanced wound contraction and epithelialization in both excision and burn wound models. In incision wound model it increased the wound breaking strength. Histological observation of excised wound revealed restoration of normal architecture of the skin. In dead space wound, the extract increased superoxide dismutase (SOD) and catalase (CAT) activity, the weight of granulation tissue and hydroxyproline content (Mondal et al., 2016).

Recently, N-butyl alcohol extract of $H$. rosa-sinensis flower was evaluated in excision wound model in rat. Hematoxylin and eosin and Masson's trichrome staining showed epithelialization, fibroblast distribution, and collagen distribution. Increased in the expression of vascular endothelial growth factor (VEGF) and 
transforming growth factor- $\beta 1$ (TGF- $\beta 1$ ) was observed by immunohistochemistry study, responsible for angiogenesis and formation of collagen fibers (Shen et al., 2017).

\section{Leea macrophylla}

Leea macrophylla (Leeaceae), is an edible plant. It is commonly known as Hastikarnapalasa (Jadhao and Wadekar, 2010). Traditionally, the plant has been reported to be effective against guinea-worm, ringworm and is applied to sores and wound (Kirtikar and Basu, 1975; Bhavamishra, 2010). Roots are applied externally to alleviate pain (Kirtikar and Basu, 1975). Pharmacologically, this plant has been reported to possess antiinflammatory (Dewanjee et al., 2013) and anti-urolithiasis (Nizami et al., 2012) effects.

The ethanolic extract of L. macrophylla roots was investigated for wound healing activity. The ethanolic extract (500 mg/kg, p.o.) and topical bioadhesive gel (5\% w/v) showed an increase in wound breaking strength. Topical application of bioadhesive gel $(5 \% \mathrm{w} / \mathrm{v})$ also increased the activity of CAT, SOD, and reduced glutathione $(\mathrm{GSH})$ and decreased lipid peroxidation (LPO). It also decreased the level of myeloperoxidase. Topical application of gel also produced favorable effects on the level of pro-inflammatory cytokines (tumor necrosis factor- $\alpha$, interleukin-1 $\beta$, and interleukin -6), and VEGF (Joshi et al., 2016).

\section{Iris florentina}

Iris florentina is a member of Iris family. This plant is copiously found in Iran, India, and China. There is no literature about the biological activity of this plant (Guo and DiPietro, 2010; Ashkani-Esfahani et al., 2012). Recently, it has been reported wound healing effect of $10 \%$ ointment of hydroalcoholic extract of a mixture of different parts of I. florentina in female Wistar rat. In this study, fibroblast population, the formation of collagen, and vascularization were determined by the histomorphometrical method in excision wound model. The ointment exhibited fibroblast proliferation, the formation of collagen, and increased vascular density Mirmalek et al., 2016).

\section{Sambucus ebulus}

Sambucus ebulus (Caprifoliaceous) is widely distributed in Iran. In Iranian herbal medicine, this plant is used for the treatment of inflammation and arthritis (Ebrahimzadeh et al., 2007). This plant is also effective against Paederus dermatitis (Ebrahimzadeh et al., 2014). Pharmacologically this plant has been reported to possess antibacterial and anti-oxidant activities and also effective against burn, wound, eczema, rash, inflammation, and rheumatism (Ebrahimzadeh et al., 2007; Süntar et al., 2010).

Wound healing activity of ointments prepared from $n$ - hexane, ethyl acetate and methanol extract of S. ebulus leaves and isolated quercetine 3-O-glucoside were studied using linear incision and circular excision wound models on Sprague Dawley rat and Swiss albino mouse. The methanolic extract ointment $(1 \%)$ showed significant wound healing activity. It also showed $84.3 \%$ contraction in circular excision wound model. The ointment also increased the wound tensile strength. The isolated compound quercetine 3-O-glucoside also showed significant wound healing property in both the model. Different subfractions obtained from methanolic extract also showed wound healing property. Histopathological study revealed collagen deposition in excision wound (Süntar et al., 2010).

In another study, ointment (5\%) of methanolic extract of S. ebulus fruits was investigated for wound healing activity by excision wound model in Wistar rat. It increased the rate of wound closure, epithelialization, and collagen formation. Application of the ointment also enhanced granulation tissue formation (Ghabaee et al., 2017).

Furthermore, wound healing progression of 2 and 5\% ointments of $70 \%$ methanolic extract of roots were studied at 7, 14, and 21 days interval in Wistar rat. The ointments increased the epidermal thickness, granulomatous tissue, new capillary formation, and the number of fibroblasts (Babaei et al., 2017).

\section{Urtica dioica}

Urtica dioica (Urticaceae) is commonly known as nettle or stinging nettle. It is an herbaceous perennial flowering plant growing in the temperate zones of Asia, America, North Africa and Europe (Borchers et al., 2000). Powdered leaf extract of this plant is traditionally used to reduce the nose bleeding and excessive menstrual flow (Mueen Ahmed and Parsuraman, 2014). In folk medicine, this plant is used for the treatment of rheumatism, arthritis, anemia and prostate diseases (Vogl et al., 2013). Pharmacologically Urtica dioica has been reported to possess anti-inflammatory (Chrubasik et al., 2007), antibacterial, anti-oxidant, hypoglycemic (Ahangarpour et al., 2012) and antiviral activities (Uncini et al., 2005).

Wound healing progression of 2 and 5\% ointment of $70 \%$ methanolic extract of a mixture of leaves, areal and roots, $U$. dioica were studied at 7,14 , and 21 days interval in rat. The ointments increased the epidermal thickness, granulomatous tissue, angiogenesis, and fibrogenesis (Babaei et al., 2017).

The efficiency of the hydroethanolic extract of $U$. dioica leaves on hemostasis and wound healing activities was investigated in Wistar rat. The extract increased the rate of excision wound closure. It also increased the tissue hydroxyproline content. Histopathological examination showed epithelial regeneration, neovascularization, 
fibroblasts, and considerable inflammatory cells. The extract also significantly increased the bleeding time (Zouari et al., 2017).

Wound healing activity of saponin fraction isolated from Algerian $U$. dioica leaves was evaluated by excision wound model in Wistar rat. Treatment of rat with crude saponin mixed with vaseline (2:10) showed $100 \%$ of wound contraction which was higher than that obtained by the standard drug (Razika et al., 2017).

\section{Wound Healing Mechanisms of Medicinal Plants}

Medicinal plants heal wound via several mechanisms such as up-regulation of VEGF and TGF- $\beta$, activation of NF- $\mathrm{kB}$, activation of interleukin-8, increased expression of iNOS and alpha- 1 type- 1 collagen, and anti-oxidant activity.

It has been demonstrated that $A$. vera and $H$. rosasinensis cause wound healing by increasing the expression of VEGF and TGF- $\beta 1$ (Mirmalek et al., 2015; Shen et al., 2017). It is well known that VEGF is responsible for angiogenesis. These growth factors act on their respective receptors present in keratinocytes and macrophages and carry out the important functions during wound healing. Insufficient vascularization is the common features of the chronic and nonhealing wound. In diabetic animal models delayed wound healing has been demonstrated, in which poor vascularization is the factor responsible for delayed wound closure, epithelialization, and granuloma tissue formation (Stallmeyer et al., 2001). TGF- $\beta$ is one of the major factors in the recent research of wound healing. It acts via intracellular SMAD pathway which regulates cell proliferation (Klass et al., 2009). TGF- $\beta$ cause migration of leukocytes into the injured tissue. As a result, monocytes transform into macrophages and clear the area of debris and itself to release TGF- $\beta$ and other growth factors, which in turn help in the formation of granulation tissue (Behm et al., 2012).

PI3K pathway plays a crucial role in wound healing by rendering proliferation of cells. Activation of PI3K pathway causes phosphorylation of Akt (serine/threoninespecific protein kinase) at serine 473 residues. This signaling pathway has been revealed to be essential for directional migration of corneal and skin epithelial cells in response to wound or injury (Vanhaesebroeck, 2006; Zhao et al., 2006). Medicinal plants are reported to induce wound healing via the PI3K pathway. For example, C. officinalis tincture encourages wound healing through activation of the PI3K pathway (Dinda et al., 2015). Aqueous extract of Korean red ginseng also kindles in vivo and in vitro angiogenesis through activetion of the PI3K/Akt pathways (Kim et al., 2007).
NF- $\mathrm{kB}$ activation is noticed in both immune and nonimmune cells affected by chronic inflammation. Activation of NF-KB increases the expression of pro-inflammatory mediators which organize and sustain the inflammatory processes which cause tissue damage. However, there are many reports are there that inhibition of NF-kB may cause harmful effect to the organisms and sometimes it may cause inflammatory disease also. The beneficial effect of NF-kB in epithelial cells has been reported. NF-kB signaling has a major role in the maintenance of immune homeostasis in epithelial cells (Wullaert et al, 2011). It has been demonstrated that plant extract can promote wound healing by NF- $\mathrm{kB}$ activation. The $\mathrm{n}$-hexane extract of $C$. officinalis has been reported to increase the activity of transcription factor NF-kB in human immortalized keratinocytes and dermal fibroblast cells (Nicolaus et al., 2017).

Interleukin-8 is a pro-inflammatory cytokine. Keratinocytes are rich in interleukin-8. Effect of recombinant interleukin- 8 on migration and adhesion of $\mathrm{HaCaT}$ keratinocytes has been demonstrated. It was found that interleukin- 8 increased the migration and adhesion of $\mathrm{HaCaT}$ keratinocytes. Interestingly it was also observed that inhibition of phospholipase C- $\gamma$ (PLC- $\gamma$ ) is completely eradicated the migration of $\mathrm{HaCaT}$ keratinocytes. Thus, interleukin- 8 directs the migration of via PLC- $\gamma$ pathway. Medicinal plant extracts also endorse wound healing by activation of interleukin- 8 . The $n$-hexane extract $C$. officinalis was found to increase the activity of interleukin-8 in human immortalized keratinocytes (Nicolaus et al., 2017).

Nitric oxide (NO) is a small radical. Synthesis of $\mathrm{NO}$ has been reported during the proliferative phase after wound formation. Increased iNOS expression release NO regulates collagen formation, cell proliferation, and wound contraction (Witte and Barbul, 2002). Moreover, iNOS regulates keratinocytes proliferation (Frank et al., 1998). Polysaccharide-rich extract of C. ferrea has been to increase the expression of iNOS (Pereira et al., 2016).

Alpha-1 type-1 collagen encoded by Col 1a (I) gene. This gene contributes to wound healing by the production of pro alpha-1 (I) chain which is a component of type 1 collagen. This pro alpha-1 (I) chain is combined with another pro alpha-1 (I) chain and also with pro alpha-2 (I) chain to produce a molecule of type I pro-collagen which undergo processing and rearrangement to produce type 1 collagen fibers. It has been demonstrated that topical application of ointment of $D$. elata showed up-regulation of alpha-1 type 1 collagen encoded by $\mathrm{Col} 1 \mathrm{la}$ (I) gene contributes to wound healing.

Rho family GTPase like Rac-1, Rho-A, and Cdc-42 plays a pivotal role in fibroblast cell proliferation and migration (D'Souza et al, 2011). Cell cycle regulators 


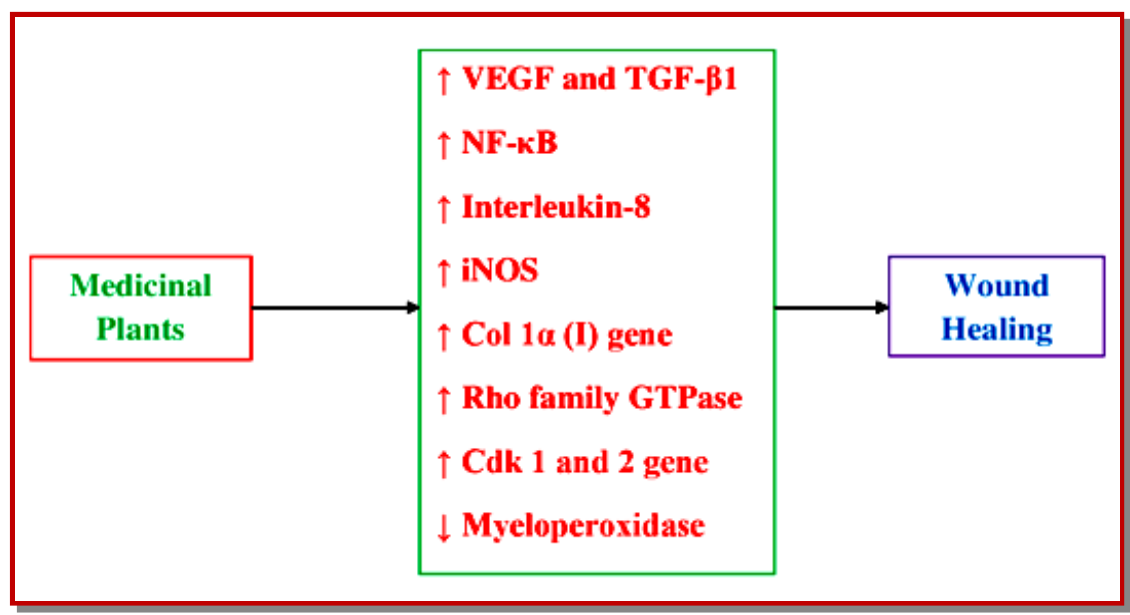

Figure 1: Mechanisms of wound healing of medicinal plants

such as cyclins, and cyclin-dependent kinase 1 and 2 are involved in cytoskeleton formation in fibroblasts (Yoshizaki et al, 2004). C. tamurana has been reported to increase the migration of mammalian cells towards the wounded area through activation of Rac-1, Rho-A, and Cdc-42 m-RNA and Cdk 1 and 2 genes.

Many shreds of evidence suggest that wound experience oxidative stress due to increased activity of neutrophils resultant oxidants and MPO activity. Increased activity of neutrophils resultant oxidants and MPO activity causes tissue damage in the chronic wound (Song et al., 2008). Generation of reactive oxygen species (ROS) results in cell toxicity via oxidative stress in chronic wound and delay wound healing (Mikhal'chik et al., 2006). Anti-oxidant activity of medicinal plants is due to the presence of various phytochemicals (Pawar et al., 2007). It has been reported that topical application of bioadhesive gel of ethanolic extract of L. macrophylla $(5 \% \mathrm{w} / \mathrm{v})$ increased the activity of catalase, superoxide dismutase, and glutathione and decreased MPO activity (Joshi et al., 2016).

Thus, medicinal plants potentiate wound healing by multiple mechanisms. Mechanisms of wound healing by medicinal plants are recapitulated in Figure 1.

\section{Conclusion}

Plants are effective wound healer and they repair wound in a natural way. This review exposed the cellular mechanisms of recently reported medicinal plants with wound healing potential which could be beneficial in therapeutic practice and development of new wound healing drugs for human use.

\section{References}

Hegazi GAEM. In vitro studies on Delonix elata L.: An endangered medicinal plant. World Appl Sci J. 2011; 14: 679_ 86.

Ahangarpour A, Mohammadian M, Dianat M. Antidiabetic effect of hydroalcholic Urtica dioica leaf extract in male rats with fructose-induced insulin resistance. Iran J Med Sci. 2012; 37: 181-86.

Ali M, Ansari SH. Hair care and herbal drugs. Indian J Nat Prod. 1997; 13: 3-5.

Artizzu N, Bonsignore L, Cottiglia F, Loy G. Studies on the diuretic and antimicrobial activity of Cynodon dactylon essential oil. Fitoterapia 1996; 67: 174-76.

Ashkani-Esfahani S, Imanieh $M$, Khoshneviszadeh $M$, Meshksar A, Noorafshan A, Geramizadeh B, Ebrahimi S, Handjani F, Tanideh N. The healing effect of Arnebia euchroma in second degree burn wounds in rat as an animal model. Iran Red Crescent Med J. 2012; 14: 70-74.

Atiba A, Ueno H, Uzuka Y. The effect of Aloe vera oral administration on cutaneous wound healing in type 2 diabetic rats. J Vet Med Sci. 2011; 73: 583-89.

Babaei E, Mohammad HA, Mehdikhani F, Milad M, Emad G, RHP. The healing effects of herbal preparations from Sambucus ebulus and Urtica dioica in full-thickness wound models. Asian Pac J Trop Biomed. 2017; 7: 421-27.

Bacchi EM, Sertie JAA. Antiulcer action of Styrax camporum and Caesalpinia ferrea in rats. Planta Med. 1994; 60: 118-20.

Balbach A. As Plantas que Curam, Três Press. São Paulo, 1972.

Basch E, Bent S, Foppa I, Haskmi S, Kroll D, Mele M, Szapary $\mathrm{P}$, Ulbricht C, Vora M, Yong S. Marigold (Calendula officinalis L.): An evidence-based systematic review by the Natural Standard Research Collaboration. J Herb Pharmacother. 2006; 6: 135-59.

Bhavamishra. Bhavaprakasa Nighantu (Indian Materia Medica). In: Chunekar, K.C., (Ed.), Chaukhambha Bharati Academy, Varanasi, 2010, pp 686-87.

Behm B, Babilas P, Landthaler M, Schreml S. Cytokines, chemokines and growth factors in wound healing. J Eur Acad Dermatol Venereol. 2012; 26: 812-20.

Bhaskar A, Nithya V. Evaluation of the wound-healing activity 
of Hibiscus rosa sinensis L (Malvaceae) in Wistar albino rats. Indian J Pharmacol. 2012; 44: 694-98.

Biswas TK, Pandit S, Chakrabarti S, Banerjee S, Poyra N, Seal T. Evaluation of Cynodon dactylon for wound healing activity. J Ethnopharmacol. 2017; 197: 128-37.

Borchers AT, Keen CL, Stern JS, Gershwin ME. Inflammation and Native American medicine: The role of botanicals. Am J Clin Nutr. 2000; 72: 339-47.

Braga R. Plantas do Nordeste, Especialmente do Ceará. Três Press. São Paulo, 1976.

Brusotti G, Andreola F, Sferrazza G, Grisoli P, Merelli A, Cuna FSRD, Calleri E, Nicotera G, Pierimarchi P, Serafino A. In vitro evaluation of the wound healing activity of Drypetes klainei stem bark extracts. J Ethnopharmacol. 2015; 175: 41221.

Brusotti G, Tosi S, Tava A, Picco AM, Grisoli P, Cesari I, Caccialanza G. Antimicrobial and phytochemical properties of stem bark extracts from Piptadeniastrum africanum (Hook f.) Brenan. Ind Crops Prod. 2013; 43: 612-16.

Carvalho JCT, Teixeira JRM, Souza PJC, Bastos JK, SantosFilho D, Sarti SJ. Preliminary studies of analgesic and antiinflammatory properties of Caesalpinia ferrea crude extract. J Ethnopharmacol. 1996; 53: 175-78.

Cesari I, Grisoli P, Paolillo M, Milanese C, Massolini G, Brusotti G. Isolation and characterization of the alkaloid Nitidine responsible for the traditional use of Phyllanthus muellerianus (Kuntze) Excell stem bark against bacterial infections. J Pharm Biomed Anal. 2015; 105: 115-20.

Chan EWC, Lim YY, Wong LF, Lianto FS, Wong SK, Lim KK, et al. Anti-oxidant and tyrosinase inhibition properties of leaves and rhizomes of ginger species. Food Chem. 2008; 109: 477-83.

Chang YC, Huang KX, Huang AC, Ho YC, Wang CJ. Hibiscus anthocyanins-rich extract inhibited LDL oxidation and oxLDL-mediated macrophages apoptosis. Food Chem Toxicol. 2006; 44: 1015-23.

Chrubasik JE, Roufogalis BD, Wagner H, Chrubasik SA. A comprehensive review on nettle effect and efficacy profiles, part I: Herba urticae. Phytomedicine 2007; 14: 423-35.

Dande P, Khan A. Evaluation of wound healing potential of Cynodon dactylon. Asian J Pharm Clin Res. 2012; 5: 161-64.

Daburkar M, Lohar V, Rathore AS, Bhutada R, Tangadpaliwar S. An in vivo and in vitro investigation of the effect of Aloe vera gel ethanolic extract using animal model with diabetic foot ulcer. J Pharm Bioallied Sci. 2014; 6: 205-12.

Dewanjee S, Dua TK, Sahu R. Potential anti-inflammatory effect of Leea macrophylla Roxb. leaves: A wild edible plant. Food Chem Toxicol. 2013; 59: 514-20.

Dinda M, Dasgupta U, Singh N, Bhattacharyya D, Karmakar P. PI3K-Mediated proliferation of fibroblasts by Calendula officinalis tincture: Implication in wound healing. Phytother Res. 2015; 29: 607-16.

D'Souza KM, Malhotra R, Philip JL, Staron ML, Theccanat $\mathrm{T}$, Jeevanandam V, Akhter SA. G protein-coupled receptor kinase-2 is a novel regulator of collagen synthesis in adult human cardiac fibroblasts. J Biol Chem. 2011; 286: 15507-16.

Eghdampour F, Jahdie F, Kheyrkhah M, Taghizadeh M, Naghizadeh S, Hagani H. The Impact of Aloe vera and Calendula on Perineal Healing after Episiotomy in Primiparous Women: A Randomized Clinical Trial. J Caring Sci. 2013; 2: 279-86.

Ebrahimzadeh MA, Mahmoudi M, Karami M, Saeedi S, Ahmadi AH, Salimi E. Separation of active and toxic portions in Sambucus ebulus. Pakistan J Biol Sci. 2007; 10: 4171 $-73$.

Ebrahimzadeh MA, Rafati MR, Damchi M, Golpur M, Fathiazad F. Treatment of Paederus dermatitis with Sambucus ebulus. Iran J Pharm Res. 2014; 13: 1065-71.

Ekor M. The growing use of herbal medicines: Issues relating to adverse reactions and challenges in monitoring safety. Front Pharmacol. 2013; 4: 1-10.

ESCOP Monographs: The scientific foundation for herbal medicinal products. United Kingdom, 2003.

Frank S, Madlener M, Pfeilschifter J, Werner S. Induction of inducible nitric oxide synthase and its corresponding tetrahydrobiopterin-cofactor-synthesizing enzyme GTPcyclohydrolase I during cutaneous wound repair. J Invest Dermatol. 1998; 111: 1058-64.

Fujita K, Hidaka M, Takamura N, Yamasaki K, Iwakiri T, Okumura M, Kodama H, Yamaguchi M, Ikenoue $\mathrm{T}$, Arimori K. Inhibitory effects of citrus fruits on cytochrome P450 3A (CYP3A) activity in humans. Biol Pharm Bull. 2003; 26: 1371-73.

Ghabaee DNZ, Ebrahimzadeh MA, Akbari J and Amiri FT. Wound healing activity of Sambucus ebulus. Int J Pharm Sci Res. 2017; 8: 132-35.

Guo S, DiPietro LA. Factors Affecting Wound Healing. J Dent Res. 2010; 89: 219-29.

Gruenwald J, Brendler T, Jaenicke C. Physician's desk reference for herbal medicines (PDR). USA, Medical Economics Company, 2000.

Hajhashemi V, Ghannadi A, Heidari AH. Anti-inflammatory and wound healing activities of Aloe littoralis in rats. Res Pharm Sci. 2012; 7: 73-78.

Herrera-Arellano A, Flores-Romero S, Chávez-Soto MA Tortoriello J. Effectiveness and tolerability of a standardized extract from Hibiscus sabdariffa in patients with mild to moderate hypertension: A controlled and randomized clinical trial. Phytomedicine 2004; 11: 375-82.

Hirunpanich V, Utaipat A, Morales NP, Bunyapraphatsara N, Sato H, Herunsale A, Suthisisang C. Hypocholesterolemic and anti-oxidant effects of aqueous extracts from the dried calyx of Hibiscus sabdariffa L. in hypercholesterolemic rats. J Ethnopharmacol. 2006; 103: 252-60.

Hosoi S, Shimizu E, Usami N, Yamamoto I, Arimori K, Okumura M, Hidaka M, Yamada M, Sakushima A. Isolation of cytochrome P450 3A (CYP3A) inhibitors from Hyuganatsu, Citrus tamurana. Hort J Nat Med. 2006; 60: 24042 .

Hou DX, Tong X, Terahara N, Luo D, Fujii M. Delphinidin 3- 
sambubioside, a Hibiscus anthocyanin, induces apoptosis in human leukemia cells through reactive oxygen speciesmediated mitochondrial pathway. Arch Biochem Biophys. 2005; 440: 101-09.

Jadhao KD, Wadekar MP. Evaluation and study of minerals from Leea macrophylla Roxb (Leeaceae). Asian J Chem. 2010; 22: $2480-82$.

Jaradat NA, Al-Ramahi R, Zaid AN. Ethnopharmacological survey of herbal remedies used for treatment of various types of cancer and their methods of preparations in the West Bank-Palestine. BMC Complement Altern Med. 2016; 16: 93.

Joshi A, Joshi VK, Pandey D, Hemalatha S. Systematic investigation of ethanolic extract from Leea macrophylla: Implications in wound healing. J Ethnopharmacol. 2016; 191: 95-106.

Kirtikar KK, Basu BD. Indian medicinal plants. 2nd Ed. Lalit Mohan Publication, India, 1980.

Kirtikar KR, Basu BD. Indian medicinal plants, M/s Bishen Singh Mahendra Pal Singh, Dehra Dun, 1975, pp 617.

Kim YM, Namkoong S, Yun YG, Hong HD, Lee YC, Ha KS, Lee H, Kwon HJ, Kwon YG, Kim YM. Water extract of Korean red ginseng stimulates angiogenesis by activating the PI3K/Akt dependent ERK1/2 and eNOS pathways in human umbilical vein endothelial cells. Biol Pharm Bull. 2007; 30: 1674-79.

Kittana N, Abu-Rass H, Sabra R, Lama M, Hanany H, Jaradat $\mathrm{N}$, Hussein F, Zaid AN. Topical aqueous extract of Ephedra alata can improve wound healing in an animal model. Chin J Traumatol. 2017; 20: 108-13.

Klass BR, Grobbelaar AO, Rolfe KJ. Transforming growth factor beta 1 signalling, wound healing and epiair: A multifunctional cytokine with clinical implications for wound repair, a delicate balance. Postgrad Med J. 2009; 85: 914.

Krishnappa P, Venkatarangaiah K, Venkatesh, Rajanna SKS, Balan RK. Wound healing activity of Delonix elata stem bark extract and its isolated constituent quercetin-3-rhamnopyranosyl-(1-6) glucopyranoside in rats. J Pharm Anal. 2016; 6: 389-95.

Kumar A, Kashyap P. Wound healing activity of Cynodon dactylon (L.) Pers. in albino Wistar rats. Int J phytopharm. 2013; 3: 63-67.

Kumar B, Vinaykumar M, Govindarajan R, Pushpangadan P. Ethanopharmacological approaches to wound healing exploring medicinal plants of India. J Ethanopharmacol. 2007; 114: 103-13.

Kupeli Akkol E, Demirel MA, Bahadir Acikara O, Süntar I, Ergene B, Ilhan M, Ozbilgin S, Saltan G, Keles H, Tekin M. Phytochemical analyses and effects of Alchemilla mollis (Buser) Rothm. and Alchemilla persica Rothm. in rat endometriosis model. Arch Gynecol Obstet. 2015; 292: 61928 .

Kurup PN, Ramdas VN, Joshi P. Handbook of medicinal plants. New Delhi, Oxford and IBH Publishing Co. Pvt. Ltd, 1979, pp 86-87.
Lazarus GS, Cooper DM, Knighton DR, Margolis DJ, Pecoraro RE, Rodeheave G, Robson MC. Definitions and guidelines for assessment of wounds and evaluation of healing. Arch Dermatol. 1994; 130: 489-93.

Leach MJ. Calendula officinalis and wound healing: A systematic review. Wounds 2008; 20: 236-43.

Li J, Chen J, Kirsener R. Pathophysiology of acute Wound healing. Clin Dermatol. 2007; 25: 9-18.

Madhyastha HM, Masatoshi Y, Hiroshi S, Tsuyomu I, Masugi M. Revealing the mechanism of in vitro wound healing properties of Citrus tamurana extract. BioMed Res Int. 2013; 2013: 1-8.

Makau JN, Watanabe K, Kobayashi N. Anti-influenza activity of Alchemilla mollis extract: Possible virucidal activity against influenza virus particles. Drug Discov Ther. 2013; 7: 189-95.

Mangathayaru K, Umadevi M, Reddy CU. Evaluation of the immunomodulatory and DNA protective activities of the shoots of Cynodon dactylon. J Ethnopharmacol. 2009; 123: 181 -84 .

Mikhal'chik EV, Anurov MV, Titkova SM. Activity of antioxidant enzymes in the skin during surgical wounds. Bulletin Exp Biol Med. 2006; 142: 667-69.

Mirmalek S, Parsa T, Parsa Y, Yadollah-Damavandi S, SalimiTabatabaee S, Jangholi E, Hosseini S, Ashkani-Esfahani S, Abooghadareh $\mathrm{H}$, Haghighifard E. The wound healing effect of Iris forentina on full thickness excisional skin wounds: A histomorphometrical study. Bangladesh J Pharmacol. 2016; 11: 86-90.

Mohamed EAK. Antidiabetic, antihypercholestermic and antioxidative effect of Aloe vera gel extract in alloxan-induced diabetic rats. Aust J Basic Appl Sci. 2011; 5: 1321-27.

Mohd AK, Saxena A, Fatima FT, Sharma G, Goud V, Husain A. Study of wound healing activity of Delonix regia flowers in experimental animal models. Am J PharmTech Res. 2012; 2: 380-90.

Mondal S, Ghosh G, Sagar N, Ganapaty S. Evaluation of Antioxidant, Toxicological and wound healing properties of Hibiscus rosa-sinensis L. (Malvaceae) ethanolic leaves extract on different experimental animal models. Indian J Pharm Edu Res. 2016; 50: 620-37.

Mueen Ahmed KK, Parsuraman S. Urtica dioica L., (Urticaceae): A stinging nettle. Sys Rev Pharm. 2014; 5: 6-8.

Muley B, Khadabadi S, Banarase N. Phytochemical constituents and pharmacological activities of Calendula officinalis Linn (Asteraceae): A review. Trop J Pharm Res. 2009; 8: 455-65.

Ngueyem TA, Brusotti G, Marrubini G, Grisoli P, Dacarro C, Vidari G, Finzi PV, Caccialanza G. Validation of use of a traditional remedy from Bridelia grandis (Pierre ex Hutch) stem bark against oral Streptococci. J Ethnopharmacol. 2008; 120: $13-16$

Najafi M, Nazemiyeh H, Garjani A, Ghavimi H, Gharekhani A. Cardioprotective effects of Cynodon dactylon against ischemia/reperfusion-induced arrhythmias. J Mol Cell Cardiol. 2007; 42: S12. 
Nakamura ES, Kurosaki F, Arisawa M, Mukainaka T, Takayasu J, Okuda M, Tokuda H, Nishino H, Pastore F. Cancer chemopreventive effects of a Brazilian folk medicine, Juca, on in vivo two-stage skin carcinogenesis. J Ethnopharmacol. 2002; 81: 135-37.

Natarajan B, Paulsen BS. An ethnopharmacological study from Thane District, Maharashtra, India: Traditional knowledge compared with modern biological science. Pharm Biol. 2000; 38: $139-51$.

Natho G, Mandaville JP. Flora of Eastern Saudi Arabia. Feddes Repertor. 1991; 102: 444.

Nayak BS, Raju SS, Orette FA, Rao AVC. Effects of Hibiscus rosa sinensis L (Malvaceae) on wound healing activity: A preclinical study in a Sprague Dawley rat. Int J Low Extrem Wounds. 2007; 6: 76-81.

Nicolaus C, Junghanns S, Hartmann A, Murillo R, Ganzera $\mathrm{M}$, Merfort I. In vitro studies to evaluate the wound healing properties of Calendula officinalis extracts. J Ethnopharmacol. 2017; 196: 94-103.

Nizami AN, Rahman MA, Ahmed NU, Islam MS. Whole Leea macrophylla ethanolic extract normalizes kidney deposits and recovers renal impairments in an ethylene glycol-induced urolithiasis model of rats. Asian Pac J Trop Med. 2012; 5: 53338.

Oliveira AF, Batista JS, Paiva ES, Silva AE, Farias YJMD, Damasceno CAR, Brito PD, Queiroz SAC, Rodrigues CMF, Freitas CIA. Evaluation of the Brazilian ironwood (Caesalpinia ferrea Mart. ex Tul. var. ferrea) healing activity on cutaneous lesions of goats. Rev Bras Plantas Med. 2010; 12: 302-10.

Oryan A, Naeini AT, Nikahval B, Gorjian E. Effect of aqueous extract of Aloe vera on experimental cutaneous wound healing in rat. Veterinarski Arhiv. 2010; 80: 509-22.

Öz BE, Ilhan M, Özbilgin S, Akkol EK, Acıkara ÖB, Saltan G, Keleş H, Süntar I. Effects of Alchemilla mollis and Alchemilla persica on the wound healing process. Bangladesh J Pharmacol. 2016; 11: 577-84.

Oudhia P. Medicinal weeds in groundnut fields of Chhattisgarh (India). Int Arachis Newslett. 1999; 19: 62-64.

Pawar RS, Khan SI, Khan IA. Glycosides of 20-deoxy derivatives of jujubogenin and pseudojujubogenin from Bacopa monniera. Planta Medica. 2007; 73: 380-83.

Parente LML, Ruy de Souza LJ, Tresvenzol LMF, Vinaud MC, de Paula JR, Paulo NM. Wound healing and antiinflammatory effect in animal models of Calendula officinalis L. growing in Brazil. Evid Based Complement Alternat Med. 2012; 2012: 1-7.

Patil MB, Jalalpure SS, Prakash NS, Kokate CK. Antiulcer properties of alcoholic extract of Cynodon dactylon in rats. Acta Hortic. 2005; 480: 115-18.

Pereira LDP, Mario RLM, Brizeno LAC, Nogueira FC, Ferreira EGM, Pereira MG, Assreuy AM. Modulator effect of a polysaccharide-rich extract from Caesalpinia ferrea stem barks in rat cutaneous wound healing: Role of TNF- $\alpha, \mathrm{IL}-1 \beta, \mathrm{NO}$, TGF- $\beta$. J Ethnopharmacol. 2016; 187: 213-23.

Priya KS, Gnanamani A, Radhakrishnan N, Babu M, Healing potential of Datura alba on burn wounds in albino rats. J Ethnopharmacol. 2002; 83: 193-99.

Puvabanditsin P, Vongtongsri R. Efficacy of Aloe vera cream in prevention and treatment of sunburn and suntan. J Med Asso Thai. 2005; 88: S173.

Razika L, Thanina AC, Nadjiba CM, Narimen B, Mahdi DM, Karim A. Anti-oxidant and wound healing potential of saponins extracted from the leaves of Algerian Urtica dioica L. Pak J Pharm Sci. 2017; 30: 1023-29.

Reuter J, Jocher A, Stump J. Investigation of the antiinflammatory potential of Aloe vera gel $(97.5 \%)$ in the ultraviolet erythema test. Skin pharmacol physiol. 2008; 21: 106-10.

Shabana MM, Mirhom YW, Genenah AA. Study into wild Egyptian plants of potential medicinal activity. Ninth communication: Hypoglycaemic activity of some selected plants in normal fasting and alloxanised rats. Arch Exp Veterinarmed. 1990; 44: 389-94.

Sampaio FC, Pereira MSV, Dias CS, Costa VCO, Conde NCO, Buzalaf MAR. In vitro antimicrobial activity of Caesalpinia ferrea Martius fruits against oral pathogens. J. Ethnopharmacol. 2009; 124: 289-94.

Sastry CST, Kavathekar YY. Plants for Reclamation of Wastelands. Publications and Information Directorate, New Delhi, India, 1990, pp 317-18.

Saroja M, Santhi R, Annapoorani S. Wound Healing Activity of Flavonoid fraction of Cynodon dactylon in swiss albino mice. Int Res J Pharm. 2012; 3: 230-31.

Sengupta R. Combined wound healing activity of Calendula officinalis and Basil leaves. J Pharmacog Phytochem. 2017; 6: $173-76$.

Sethi N, Nath D, Singh RK. Teratological study of an indigenous antifertility medicine, Hibiscus rosa sinensis in rats. Arogya J Health Sci. 1986; 12: 86-88.

Shadhan RM, Bohari SPM. Effects of Hibiscus sabdariffa Linn. fruit extracts on a-glucosidase enzyme, glucose diffusion and wound healing activities. Asian Pac J Trop Biomed. 2017; 7: 466-72.

Shafeie N, Naini AT, Hossein KJ. Comparison of different concentrations of Calendula officinalis gel on cutaneous wound healing. Biomed Pharmacol J. 2015; 8: 979-92.

Shen HM, Chen C, Jiang JY, Zheng YL, Cai WF, Wang B, Ling Z, Tang L, Wang YH, Shi GG. The N-butyl alcohol extract from Hibiscus rosa-sinensis L. flowers enhances healing potential on rat excisional wounds. J Ethnopharmacol. 2017; 198: 291-301.

Singh MP, Singh RH, Udupa KN. Antifertility activity of a benzene extract of Hibiscus rosa sinensis flowers on female albino rats. Planta Medica. 1982; 44: 171-74.

Singh SK, Rai PK, Jaiswal D, Rai DK, Sharma B, Watal G. Protective effect of Cynodon dactylon against STZ induced hepatic injury in rats. J Ecophysiol Occup Health. 2008a; 8: 195-99.

Singh SK, Rai PK, Jaiswal D, Watal G. Evidence-based critical evaluation of glycemic potential of Cynodon dactylon. Evid 
Based Complement Alternat Med. 2008b; 5: 415-20.

Soltanipoor MA. Introduction to the Flora, Life Form and Chorology of Hormoz Island Plants, S. Iran, Rostaniha 2006; 7: 19-32.

Song HS, Park TW, Sohn UD, Shin YK, Choi BC, Kim CJ, Sim SS. The effect of caffeic acid on wound healing in skinincised mice. Korean J Physiol Pharmacol. 2008; 12: 343-47.

Stallmeyer B, Pfeilschifter J, Frank S. Systemically and topically supplemented leptin fails to reconstitute a normal angiogenic response during skin repair in diabetic ob/ob mice. Diabetologia 2001; 44: 471.

Sunday AG, Ifeanyi OE, Ezeja MI. Wound healing potentials of leaf and bark extracts of Delonix regia. World J Pharm Pharm Sci. 2014 ; 3: 133-42.

Süntar IP, Akkol EK, Yalçin FN, Koca U, Keleş H, Yesilada E. Wound healing potential of Sambucus ebulus L. leaves and isolation of an active component, quercetin 3-O-glucoside. J Ethnopharmacol. 2010; 129: 106-14.

Takzare N, Hosseini MJ, Hasanzadeh G, Mortazavi H, Takzare A, Habibi P. Influence of Aloe Vera gel on dermal wound healing process in rat. Toxicol Mech Methods. 2009; 19: 7377 .

Trendafilova A, Todorova M, Nikolova M, Gavrilova A, Vitkova A. Flavonoid constituents and free radical scavenging activity of Alchemilla mollis. Nat Prod Commun. 2011; 6: 1851-54.

Uncini Manganelli RE, Zaccaro L, Tomei PE. Antiviral activity in vitro of Urtica dioica L., Parietaria diffusa M. et K. and Sambucus nigra L. J Ethnopharmacol. 2005; 98: 323-27.

Vanhaesebroeck B. Charging the batteries to heal wounds through PI3K. Nat Chem Biol. 2006; 2: 453-55.

Vogl S, Picker P, Mihaly-Bison J, Fakhrudin N, Atanasov AG, Heiss EH, Wawrosch C, Reznicek G, Dirsch VM, Saukel
J, Kopp B. Ethnopharmacological in vitro studies on Austria's folk medicine: An unexplored lore in vitro anti-inflammatory activities of 71 Austrian traditional herbal drugs. J Ethnopharmacol. 2013; 149: 750-71.

Witte MB, Barbul A. Role of nitric oxide in wound repair. Am J Surg. 2002; 183: 406-12.

Wullaert A, Bonnet MC, Pasparakis M. NF-kB in the regulation of epithelial homeostasis and inflammation. Cell Res. 2011; 21: $146-58$

Yoshizaki H, Ohba Y, Parrini MC, Dulyaninova NG, Bresnick AR, Mochizuki N, Matsuda M. Cell type-specific regulation of RhoA activity during cytokinesis. J Biol Chem. 2004; 279: 44756-62.

Yagi A, Hegazy S, Kabbash A. Possible hypoglycemic effect of Aloe Vera L. high molecular weight fractions on type, 2009; 2: 209-15.

Yamaguchi M, Sameshima H, Ikenoue T, Tsuboi M, Hidaka M, Arimori K. Hyuganatsu orange (Citrus tamurana Hort. Ex Tanaka) contains a water soluble substance that suppresses bone loss in ovariectomized rats. Biosci Biotech Biochem. 2012; 76: 364-67.

Yarnel E, Abascal K. Multiphasic herbal prescribing for menstruating women. Alternat Complement Ther. 2009; 15: 126-34.

Zhao M, Song B, Pu J, Wada T, Reid B, Tai G, Wang F, Guo A, Walczysko P, Gu Y, Sasaki T, Suzuki A, Forrester JV, Bourne HR, Devreotes PN, McCaig CD, Penninger JM. Electrical signals control wound healing through phosphatidylinositol-3-OH kinase-gamma and PTEN. Nature 2006; 442: 457-60.

Zouari BK, Bardaa S, Khimiri M, Rebaii T, Tounsi S, Jlaiel L, Trigui M. Exploring the Urtica dioica leaves hemostatic and wound-healing potential. Biomed Res Int. 2017; 2017: 1-10. 